\title{
Tear film and ocular surface changes in diabetes mellitus
}

\author{
Alterações do filme lacrimal e da superficie ocular no diabetes mellitus
}

\author{
Mônica de Cássia Alves ${ }^{1}$ \\ José Barreto Carvalheira ${ }^{2}$ \\ Carolina Maria Módulo ${ }^{3}$ \\ Eduardo Melani Rocha ${ }^{4}$
}

\begin{tabular}{|l|}
\hline ABSTRACT \\
\hline Diabetes mellitus and its clinical association with dry eye and ocular \\
surface are becoming a frequent and sometimes complicate problem in \\
Ophthalmology. Epidemiological data show that an increase in the \\
number of patients with this association is expected following the trend \\
to rise of the disease. The present work reviews the clinical and functional \\
aspects of this problem. The observations indicate that metabolic, \\
neuropathic and vascular tissue damages lead to an inflammatory process \\
and functional degeneration. The physiopathological mechanism include \\
hyperglycemia, advanced glycated end product accumulation, oxidative \\
stress and inflammationmediated by NF- $\mathrm{\kappa B}$ signaling pathways. Potential \\
treatments enlightened by those findings would include antioxidant, \\
anti-inflammatory, secretagogues and/or anabolic agents that would \\
mimic insulin effects.
\end{tabular}

Keywords: Dry eye syndromes/physiopathology; Diabetes mellitus; Oxidative stress; Physiopathology; Models, animal; Tears
Trabalho realizado na Faculdade de Medicina de Ribeirão Preto da Universidade de São Paulo - USP - Ribeirão Preto (SP) - Brasil.

Doutora, Professora da Faculdade de Ciências Médicas da Pontifícia Universidade Católica de Campinas PUC - Campinas (SP) - Brasil.

${ }^{2}$ Doutor, Professor do Departamento de Clínica Médica da Faculdade de Ciências Médicas da Universidade Estadual de Campinas - UNICAMP - Campinas (SP) Brasil.

${ }^{3}$ Bióloga, Pós-graduanda do Departamento de Oftalmologia, Otorrinolaringologia e Cirurgia de Cabeça e Pescoço da Faculdade de Medicina de Ribeirão Preto da Universidade de São Paulo - USP - Ribeirão Preto (SP) - Brasil.

${ }^{4}$ Professor Associado do Departamento de Oftalmologia, Otorrinolaringologia e Cirurgia de Cabeça e Pescoço da Faculdade de Medicina de Ribeirão Preto da Universidade de São Paulo - USP - Ribeirão Preto (SP) - Brasil.

Corresponding author: Eduardo M. Rocha. Departamento de Oftalmologia Otorrinolaringologia e Cirurgia de Cabeça e Pescoço - FMRP - Universidade de São Paulo - USP. Av. Bandeirantes, 3900 - Ribeirão Preto (SP) CEP 14049-900

E-mail: emrocha@fmrp.usp.br

Financial Support: CAPES, CNPq, FAPESP

\section{INTRODUCTION}

Diabetes mellitus along with aging are probably the major risk factors responsible for ocular diseases ${ }^{(1-2)}$. Besides the well-known complications, as cataract and diabetic retinopathy, in the last fifteen years, it was better characterized the relationship with dry eye and ocular surface disorders ${ }^{(3-6)}$.

Considering the increasing incidence of diabetes mellitus and the perspective of growing importance of its implications in ocular surface, the present work will review the clinical and physiopathological aspects of lacrimal gland and ocular surface dysfunctions in this disease ${ }^{(7-8)}$. Moreover, it will review the state of the art of experimental research in the field and potential new treatments for those conditions.

\section{Diabetes mellitus: an overview of the problem}

Diabetes mellitus is the most common metabolic disease worldwide and its hallmark is hyperglycemia. Despite periods of feeding and fasting, plasma glucose remains within a narrow range between 4 and $7 \mathrm{mM}$ (72 to $126 \mathrm{mg} / \mathrm{dl}$ ) in normal individuals. This tight control is governed by the balance between glucose absorption from the intestine, production by the liver and uptake and metabolism by peripheral tissues. Insulin increases glucose uptake in muscle and fat, and inhibits hepatic glucose production, thus serving as the primary regulator of blood glucose concentration ${ }^{(9-10)}$.

Type 1 diabetes results from the autoimmune destruction of pancreatic $\beta$ cells causing insulin deficiency. Type 2 diabetes accounts for $>90 \%$ of cases and is characterized by a triad of (a) resistance to insulin action on 
glucose uptake in peripheral tissues, especially skeletal muscle and adipocytes, (b) impaired insulin action to inhibit hepatic glucose production, and (c) dysregulated insulin secretion $^{(10)}$. In most cases, Type 2 diabetes is a polygenic disease with complex inheritance patterns ${ }^{(11)}$. Environmental factors, especially diet, physical activity, and age, interact with genetic predisposition to affect disease prevalence. Susceptibility to both insulin resistance and insulin secretory defects appear to be genetically determined ${ }^{(11)}$. Defects in insulin action precede the overt disease and are seen in non diabetic relatives of diabetic subjects. Initially, increased insulin secretion compensates for insulin resistance but overt disease occurs over time as $\beta$ cell compensation fails. Other specific types of diabetes were added, including one due to genetic defects in $\beta$-cell function and genetic defects in insulin action, along with diseases of the exocrine pancreas, and drug-induced or chemically induced diabetes. Finally, the type of diabetes diagnosed during pregnancy, gestational diabetes mellitus, was considered independently (Table 1).

Besides chronic hyperglycemia, all forms of diabetes are characterized by the development of diabetes-specific microvascular pathology in the retina, renal glomerulus and peripheral nerve. As a consequence of its microvascular pathology, diabetes is a leading cause of blindness, end stage renal disease and a variety of debilitating neuropathies ${ }^{(12)}$. Diabetes is also associated with accelerated atherosclerotic macrovascular disease affecting arteries that supply the heart, brain and lower extremities. As a result, patients with diabetes have a much higher risk of myocardial infarction, stroke and limb amputation. Large prospective clinical studies show a strong relationship between glycemia and diabetic microvascular complications in both type 1 and type 2 diabetes $^{(13-14)}$. Hyperglycemia and insulin resistance both seem to have important roles in the pathogenesis of macrovascular complications ${ }^{(15-17)}$.

\begin{tabular}{|lll|}
\hline Table 1. Classification and observations on types of diabetes mellitus \\
Type & Characteristic & Clinical comment \\
Type 1 & $\begin{array}{l}\text { Autoimmune, previously } \\
\text { called juvenile or } \\
\text { insulin-dependent } \\
\text { diabetes mellitus }\end{array}$ & $\begin{array}{l}\text { Potential association } \\
\text { with other autoimmune } \\
\text { diseases }\end{array}$ \\
Type 2 & $\begin{array}{l}\text { Polygenic and influenced } \\
\text { by environment }\end{array}$ & $\begin{array}{l}\text { Increasing incidence } \\
\text { associated with higher } \\
\text { life span and western } \\
\text { cultural habits }\end{array}$ \\
& $\begin{array}{l}\text { Aggressive clinical } \\
\text { progress }\end{array}$ & $\begin{array}{l}\text { May persist after } \\
\text { pregnancy }\end{array}$ \\
Secondary & $\begin{array}{l}\text { Side effect of medications } \\
\text { or pancreas dysfunction } \\
\text { (e.g.; steroids, chronic }\end{array}$ & $\begin{array}{l}\text { medication may also } \\
\text { influence ocular and } \\
\text { lacrimal function }\end{array}$ \\
alcoholism) & $\begin{array}{l}\text { Genetic defects in insulin } \\
\text { secretion or action }\end{array}$ & $\begin{array}{l}\text { Potential ocular } \\
\text { associated } \\
\text { malformations }\end{array}$ \\
\hline
\end{tabular}

Diabetes-specific microvascular disease in the retina, glomerulus and vasa nervorum has similar physiopathological features. Early in the course of diabetes, intracellular hyperglycemia causes abnormalities in blood flow and increased vascular permeability. This reflects decreased activity of vasodilators such as nitric oxide, increased activity of vasoconstrictors such as angiotensin II and endothelin-1, and elaboration of permeability factors such as vascular endothelial growth factor (VEGF). Quantitative and qualitative abnormalities of extracellular matrix contribute to an irreversible increase in vascular permeability. With time, microvascular cell loss occurs, in part as a result of programmed cell death, and there is progressive capillary occlusion due both to extracellular matrix overproduction induced by growth factors such as transforming growth factor- $\beta$ (TGF- $\beta$ ), and to deposition of extravasated periodic acid-Schiff-positive plasma proteins. Hyperglycemia may also decrease production of trophic factors for endothelial and neuronal cells. Together, these changes lead to edema, ischemia and hypoxia-induced neovascularization in the retina, proteinuria, mesangial matrix expansion and glomerulosclerosis in the kidney, and multifocal axonal degeneration in peripheral nerves (Figure 1). Although microvascular diabetic alterations have never been studied in lacrimal gland or ocular surface, a well-known complication, in part attributed to peripheral nerve degeneration, is diabetic neurotrophic keratopathy ${ }^{(18-19)}$.

In diabetic arteries, endothelial dysfunction seems to involve both insulin resistance specific to the phosphatidylinositol-3 kinase/Akt pathway ${ }^{(20-23)}$ and hyperglycemia ${ }^{(12)}$. Pathway-selective insulin resistance results in decreased endothelial production of the antiatherogenic molecule nitric oxide, and increased potentiation of proliferation of vascular smooth muscle cells and production of plasminogen activator inhibitor-1 (PAI-1) via the Ras $\rightarrow$ Raf $\rightarrow$ MEK kinase $\rightarrow$ mitogen-activated protein (MAP) kinase pathway ${ }^{(20)}$. Hyperglycemia itself also inhibits production of nitric oxide in arterial endothelial cells ${ }^{(24)}$ and stimulates production of PAI-124) (Figure 2).

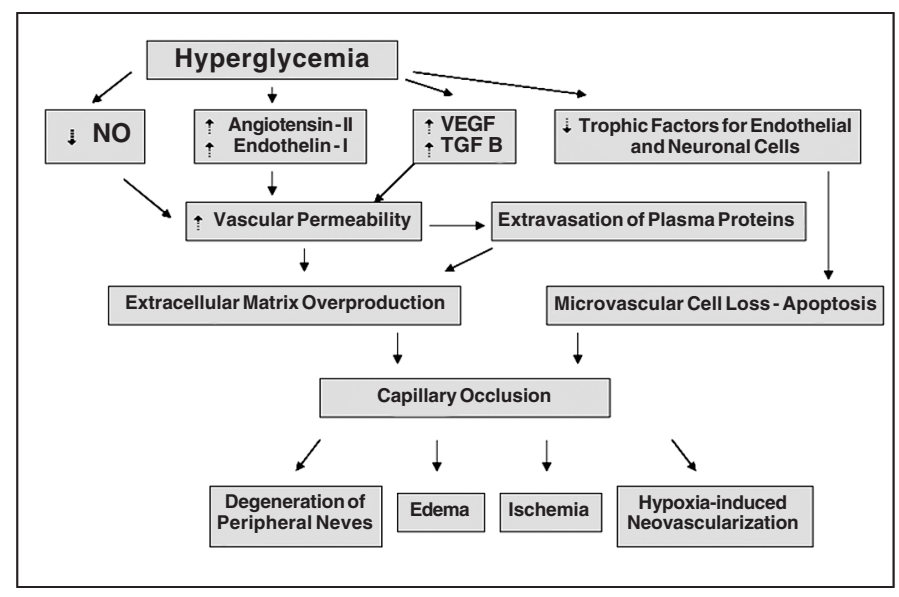

Figure 1 - Biochemical mediators and events related to diabetes mellitus that lead to capillary occlusion and peripheral tissue damage 
Both insulin resistance and hyperglycemia also participate in the pathogenesis of diabetic dyslipidemia, which is implicated in dry eye and ocular surface disease in humans and animal models ${ }^{(1,25)}$. Hyperglycemia seems to cause raised levels of atherogenic cholesterol-enriched apolipoprotein B-containing remnant particles by reducing expression of the heparan sulphate proteoglycan perlecan on hepatocytes ${ }^{(15)}$. Associations of atherosclerosis and atherosclerosis risk factors with glycemia have been shown over a broad range of glucose tolerance, from normal to diabetic. Of interest, postprandial hyperglycemia may be more predictive of atherosclerosis than is fasting plasma glucose level or hemoglobin $\mathrm{A} 1 \mathrm{c}^{(26)}$.

Another major consequence of the hyperglycemia and oxidative stress observed in diabetes mellitus is the formation of compounds as a result of the chemical reaction of the glucose with proteins. These compounds, known as AGEs (advanced glycation end-products), accumulate and modify the structure of the protein matrix of many different tissues and activate pro-inflammatory cytokines leading to the cellular damage associated with the complications of diabetes in kidney, blood vessels, retina, lens and lacrimal gland ${ }^{(27-28)}$.

The nuclear factor-kappaB (NF- $\mathrm{KB})$ is a signaling protein, whose activation cascade could be activated by hyperglycemia, AGEs and/or oxidative stress. The cellular response in-

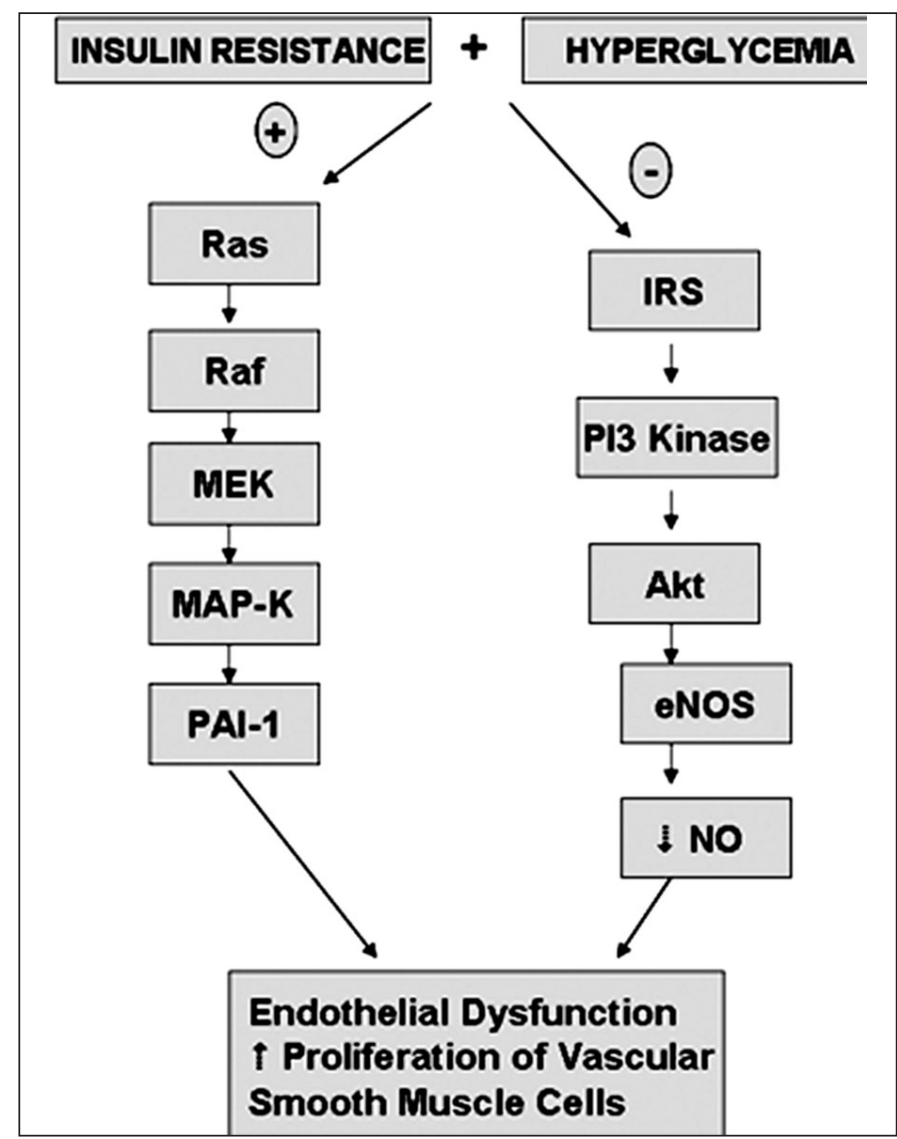

Figure 2 - Signaling mechanisms related to endothelial damage in diabetes mellitus volves transcription of a large number of genes, associated with cellular response to stress, such as the TNF- $\alpha$, and interleukin-1 $\beta$ and in a chronic condition it may lead to tissue damage and organ dysfunction ${ }^{(29-30)}$ (Figure 3).

The identification of AGEs on ocular tissues have suggested their association with diabetic complications ${ }^{(28,31)}$. Despite a clear correlation between AGEs and oxidative damage and tissue dysfunction, the possibility of direct microvascular damage contribution on lacrimal gland or ocular surface alterations in diabetes mellitus was not investigated.

It is now clear that aggressive control of hyperglycemia in patients with type 1 and 2 diabetes can attenuate the development of chronic complications such as retinopathy and nephropathy ${ }^{(13-14)}$. At present, therapy for type 1 and 2 diabetes relies mainly on several approaches intended to reduce the hyperglycemia itself: sulphonylureas, metformin, peroxisome proliferator-activated receptor- $\gamma(\operatorname{PPAR} \gamma)$ agonists (thiazolidinediones), $\alpha$-glucosidase inhibitor and insulin. These therapies have limited efficacy, limited tolerability and significant mechanism-based side effects. Of particular concern is the tendency of most treatments to enhance weight gain $^{(7,32)}$ (Table 2).

\section{Impact of diabetes mellitus on ocular surface and tear film}

The ocular surface alterations in diabetes mellitus have been studied more carefully in the last 2 decades and their reported complaints by diabetic patients are becoming more frequent in the clinical daily practice and strategies for their prevention and amelioration are increasingly recognized.

Clinical studies revealed the clinical manifestations of diabetes mellitus, associated with lacrimal gland and ocular surface dysfunctions related to dry eye syndrome ${ }^{(3-5)}$.

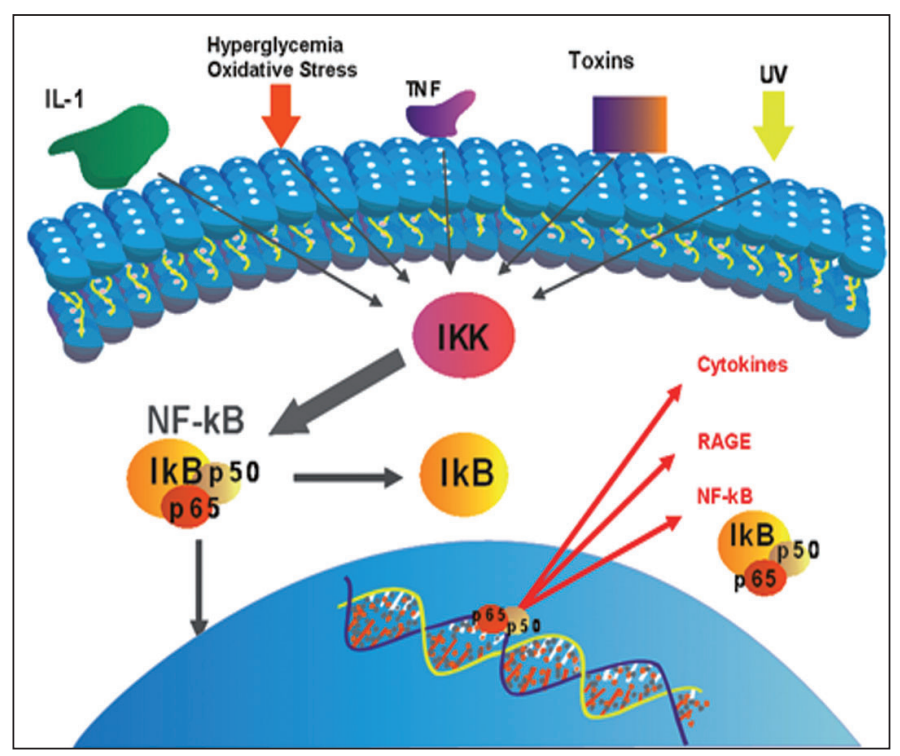

Figure 3 - Extracellular stimuli for advanced glycated end products production and NF-KB signaling activation, cytokines production and tissue impairment 
Corneal and conjunctival epithelial alterations, persistent epithelial defects, which are frequently associated with evident fragility during intraocular surgeries, and potential visual impairment due to corneal scaring have been obser$\operatorname{ved}^{(5,19,33-37)}$. Those pathological alterations are not limited to anterior layers of the cornea ${ }^{(38-39)}$.

A potential explanation combines chronic tear secretion deficiency, peripheral neuropathy and hyperglycemia leading to corneal epitheliopathy with complications as hyperosmolarity punctate keratopathy, recurrent erosions, persistent epithelial defects, neurotrophic keratopahty, wound healing delay, and higher risk of microbial keratitis ${ }^{(40-42)}$ (Figure 4).

Although with very heterogeneous clinical presentation and course in population terms, diabetic patients frequently complain of typical dry eye symptoms, such as burning and foreign body sensation ${ }^{(5,42)}$. In more severe cases, the combination with diabetic neurotrophic keratopathy would help to explain the absence of symptoms or apparent tolerance to dryness and epitheliopathy. In initial and mild cases, tran- sient visual acuity reduction due to tear film instability may be also present ${ }^{(43)}$.

The most frequent and measurable clinical findings are reduced tear secretion, tear film instability, higher grade of conjunctival squamous metaplasia, lower goblet cell density and reduced corneal sensation, but diabetes mellitus also reduces the lipid layer of the tear film ${ }^{(4-5,40,44)}$.

The correlation between diabetes mellitus duration or diabetic retinopathy and diabetic complications in the ocular surface is controversial in the medical literature ${ }^{(5,42,45)}$. Moreover, the probability of other ocular complications worsening on later introduction of systemic insulin in the treatment, as reported in diabetic retinopathy is not clear ${ }^{(46)}$.

\section{Experimental models for understanding exocrine gland and ocular surface dysfunction in DM}

Among the experimental animal models to study ocular complications of diabetes mellitus, the most used are rodents.

\begin{tabular}{|c|c|c|}
\hline Drug & Mechanism of action & Potential ocular implications \\
\hline $\begin{array}{l}\text { Sulphonylureas and related } \\
\text { insulin secretagogues }\end{array}$ & $\begin{array}{l}\text { Increase insulin release } \\
\text { from pancreatic islets }\end{array}$ & $\begin{array}{l}\text { Reduction of risk of diabetic } \\
\text { ocular complications }{ }^{(32)}\end{array}$ \\
\hline Metformin & $\begin{array}{l}\text { Reduce hepatic } \\
\text { glucose production }\end{array}$ & $\begin{array}{l}\text { Higher overall risk reduction } \\
\text { with lower side effects( }{ }^{(32)}\end{array}$ \\
\hline $\begin{array}{l}\text { Peroxisome proliferator- } \\
\text { activated receptor- } \gamma \text { agonists } \\
\text { (thiazolidinediones) }\end{array}$ & Enhance insulin action & $\begin{array}{l}\text { Inhibition of IL-1 } \beta \text {, endothelial } \\
\text { cells apoptosis and micro } \\
\text { vascular proliferation }{ }^{(82-83)}\end{array}$ \\
\hline$\alpha$-Glucosidase inhibitors & $\begin{array}{l}\text { Decrease the absorption } \\
\text { and ingestion of carbohydrates } \\
\text { from the intestine }\end{array}$ & $\begin{array}{l}\text { Potential role on ocular tissue } \\
\text { development and metabolism }\end{array}$ \\
\hline Insulin & $\begin{array}{l}\text { Suppresses glucose production } \\
\text { and augments glucose utilization }\end{array}$ & $\begin{array}{l}\text { Reduction of risk of diabetic ocular } \\
\text { complications }{ }^{(13)} \text {. Tissue differentiation, } \\
\text { growth, metabolism and extrapancreatic } \\
\text { production }{ }^{(54,72)}\end{array}$ \\
\hline
\end{tabular}
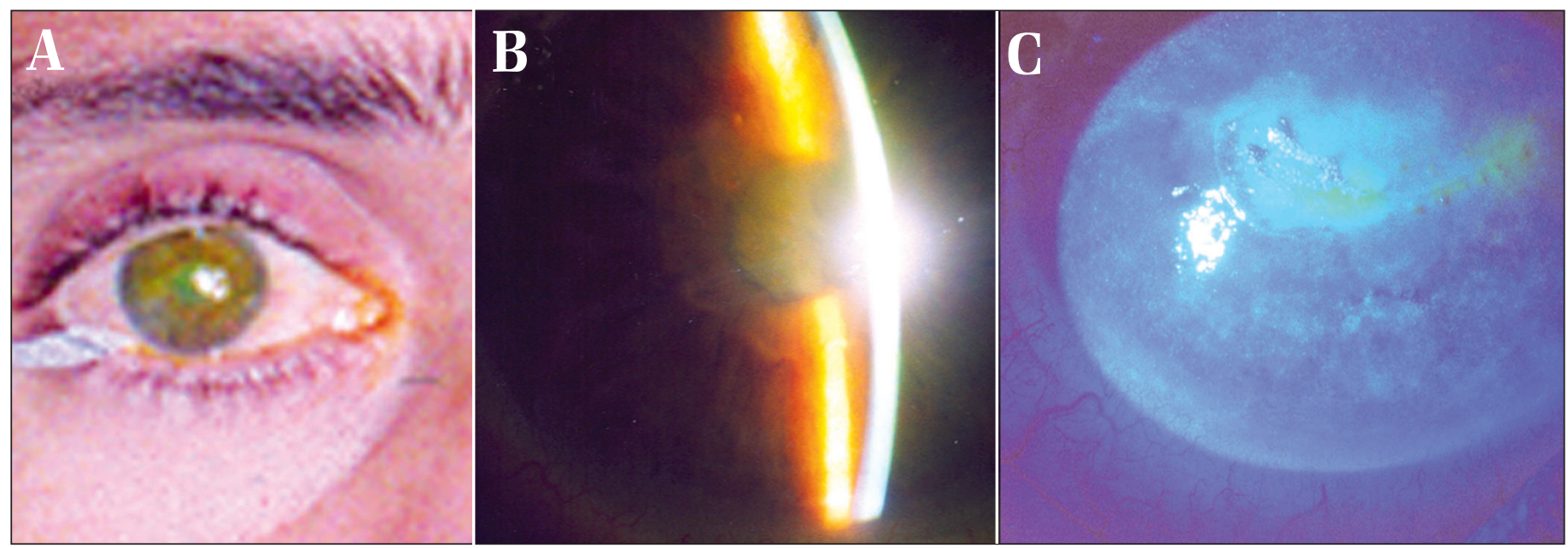

Figure 4 - (A) 36 years old male patient with DM type 1 for 6 years. His clinical profile included peripheral neuropathy, nephropathy and proliferative diabetic retinopathy. His eye examination also revealed severely reduced visual acuity and Schirmer test lower than 2 mm in both eyes; (B) Slit lamp aspect of ocular surface with corneal edema and cataracts; (C) Fluorescein dye revealed short tear film break-up time and punctuate keratitis. 
The systemic injection of alloxan or streptozotocin induces a toxic damage to pancreatic islets and leads to a condition similar to DM type $1^{(47-48)}$. In addition, lower and early doses of streptozotocin are able to simulate the conditions of DM type $2^{(49)}$. In diabetic rats, reduced tear film secretion, cataracts and salivary gland dysfunction after 4-5 weeks, corneal epithelia alterations and wound healing delay after 8-10 weeks, and histological damage of retina after 40 weeks are the ocular diseases that have been reported ${ }^{(50-53)}$.

The possibility that a direct toxic effect of streptozotocin on peripheral tissues would be confounded with diabetic complications was not proven in a recent study with rat lacrimal glands ${ }^{(54)}$.

Non-obese diabetic mice are spontaneous models of DM type 1 , however, the autoimmune process also directly involves exocrine glands. Moreover, dacryoadenitis has a higher incidence and presents earlier in males ( 8 weeks of life) than in females (30 weeks of life) $)^{(55-56)}$.

The Goto-Kakizaki rat is a model of diabetes mellitus type 2, with Wistar wild background. Its functional and cellular characterization of ocular surface damage and dry eye after 13-15 weeks of life was recently described ${ }^{(57)}$.

In streptozotocin diabetic rat, progressive histological damage of lacrimal gland and lipofucsin-like deposits in acinar cells were observed (unpublished data). The expression of insulin receptor and other signaling elements were preserved at 4 weeks, their role attributed to metabolic control and cell proliferation, but their activation was impaired in diabetic lacrimal and salivary glands ${ }^{(58-59)}$. Other peptide membrane receptors, as orexin, ghrelin and growth hormone were also identified, however their functional aspects are undetermined $^{(60)}$.

Comparable, but not exactly similar findings between rat exorbital lacrimal gland and parotid and/or submandibular salivary glands were also be observed in diabetes mellitus. They include similar impact on histology, function ad signaling mechanisms ${ }^{(58,61)}$. Evidences of oxidative stress secondary to hyperglicemia has been explored for a long time and was suggested to contribute to cell damage and exocrine gland dysfunction ${ }^{(28,62-63)}$.

Hyperglycemia involves expression of the inflammatory cytokines of the innate immune system, as TNF- $\alpha$ and IL- $1 \beta$, which are clearly involved in lacrimal gland impairment in other animal models ${ }^{(28,64-65)}$. A unified mechanism that links hyperglicemia, oxidative stress, inflammation and LG dysfunction has been attributed to NF- $\mathrm{\kappa B}$ signaling pathways ${ }^{(28)}$. The post-transcriptional events do not only respond to the aggression but also amplify and perpetuate it (Figure 3).

Impairment of wound closure and cornea reepithelization has been studied in diabetic animal models ${ }^{(66-68)}$. Apart a proven beneficial effect of growth factors on corneal epithelium proliferation, it is clear that correction to a normoglycemic state and/or topical insulin ameliorates corneal reepithelization ${ }^{(53,69-71)}$. Moreover, studies with cultured epithelial cells reveals that insulin is able to better preserve phenotypic characteristics of corneal epithelia ${ }^{(72)}$. Therefore, insulin acts and promote its effects in a similar way as growth factors do.

An unexpected recent finding in the lacrimal gland of streptozotocin-induced diabetic rat was the persistence of insulin transcription, expression and secretion. This finding includes lacrimal gland as an extrapancreatic source of insulin, even in conditions mimicking diabetes mellitus type $1^{(54,73)}$.

\section{Molecular mechanisms of diabetic alterations in ocular surface and lacrimal gland}

It had been suggested that one or more of the following initial events may lead to the alterations described in the tear film and ocular surface of diabetic patients: a) chronic hyperglycemia, b) corneal nerve damage and c) impairment on insulin action.

Those events contribute to tissue injury and may create an environment for inflammation, as a non-specific response that increases and perpetuates the tissue injury. As observed before, inflammatory proteins are produced and are implicated in diabetic complications in the early and subclinical stages of disease. The progressive peripheral neural damage is an example of afferent and efferent neural signaling pathway, that once damaged, as in neurotrophic keratitis interrupts the anti-inflammatory neural feedback ${ }^{(74-76)}$.

Insulin exerts important metabolic and mitogenic effects on several target tissues through the mediation of nutrient influx, energy storage, gene expression and protein synthesis. Exocrine gland secretions such as tears, saliva and milk contain insulin, which support the metabolism and growth of these glands. Their relevance for corneal and lacrimal gland epithelial cell proliferation and culture maintenance was also indicated ${ }^{(59,77-78)}$

The identification of insulin in the tear film and the presence of both insulin and insulin-like growth factor-1 (IGF-1) receptors in the human ocular surface reinforce this perception $^{(79)}$. Its also interesting to note that some growth factors previously identified as epithelial growth promoters such as epidermal and nerve growth factors, share similar mechanisms of signal transduction with insulin ${ }^{(80)}$.

In streptozotocin diabetes-induced animal models, a higher expression of AGE, its receptor and NF- $\kappa \mathrm{B}$ in was demonstrated lacrimal gland and ocular surface compared to controls, as being a result of hyperglycemia. These findings suggest that more than to induce a signaling cascade that leads to oxidative damage and inflammatory alterations, it may impair routine biochemical intracellular events, culminating with reduced tear secretion and dry eye syndrome ${ }^{(28)}$.

Corneal nerve alterations, probably caused by direct hyperglycemic and/or microvascular damage to the tissue lead to neurotrophic lesion and block the feedback mechanism that controls tear secretion ${ }^{(18,41)}$. They seem to occur later in the process, but certainly have a crucial role in severe presentations of the diabetic dry eye.

Based on experimental studies and recently elucidated mechanisms of disease, several potential treatments have 


\begin{tabular}{|ll|}
\hline \multicolumn{2}{|c|}{$\begin{array}{c}\text { Table 3. Potential treatment for ocular surface disorders related to } \\
\text { diabetes }\end{array}$} \\
Mechlitus
\end{tabular}

been suggested for ocular surface alterations and dry eye syndrome related to diabetes mellitus (Table 3). Anti-AGE agents have shown a potential protective effect against renal disease and retinopathy in the context of chronic hyperglycemia and AGE accumulation ${ }^{(81)}$.

In response to oxidative damage, a clinical study indicated that daily supplementation of vitamin $\mathrm{C}$ and $\mathrm{E}$ can improve some parameters of ocular surface evaluation in diabetic patients ${ }^{(82)}$.

Other potential treatments, although not clinically tested, to revert diabetic local damage to lacrimal gland tissue, would include aspirin, known for decades to counterpose diabetic complications and recently demonstrated to inhibit $\mathrm{NF}-\kappa \mathrm{B}$ signaling cascade ${ }^{(83-84)}$. In the same way, PPAR $\gamma$ agonists may be useful to improve lacrimal gland secretion by inhibition of IL-1 $\beta$ production of nitric oxide ${ }^{(85)}$.

\section{CONCLUSIONS}

Following the projections, incidence of dry eye and ocular surface damage due to diabetes mellitus trends to increase, following the rise of the disease in the future. By now, their correlations with other diabetic complications were not established since those clinical events have not been included as parameters in large population studies of diabetes mellitus. The treatment involves artificial tears and intensive care in cases of corneal epithelial defects. The potential role of topical anti-inflammatory/oxidant or mitogenic therapy is being addressed by experimental studies and may be confirmed in longer and controlled clinical trials.

Better treatments and preventive strategies for dry eye syndrome and ocular surface alterations related to diabetes mellitus will be available with the fine understanding of their specific mechanisms, involving hyperglycemia, and its many consequences such as oxidative, inflammatory and neurotrophic damage.

\section{RESUMO}

O diabetes mellitus e sua associação clínica com olho seco e doença da superfície ocular estão se tornando um problema freqüente e muitas vezes complicado em oftalmologia. Os dados epidemiológicos mostram que o número de casos deve crescer acompanhando a tendência de aumento da incidência da doença. Esse trabalho revê seus aspectos clínicos e funcionais. As observações indicam que as lesões metabólicas, neuropáticas e vasculares levam a um processo inflamatório e degeneração funcional. Os mecanismos fisiopatológicos incluem hiperglicemia, acúmulo de produtos finais de glicosilação avançada, estresse oxidativo e inflamação mediada pelas vias de sinalização do NF-kB. Os tratamentos potenciais sugeridos por essas observações incluiriam antioxidantes, antiinflamatórios, secretagogos e/ou agentes anabólicos com efeitos miméticos ao da insulina.

Descritores: Síndrome do olho seco/fisiopatologia; Diabetes mellitus; Estresse oxidativo; Modelos animais; Lágrimas

\section{REFERENCES}

1. Moss SE, Klein R, Klein BE. Prevalence of and risk factors for dry eye syndrome. Arch Ophthalmol. 2000;118(9):1264-8.

2. Moss SE, Klein R, Klein BE. Incidence of dry eye in an older population. Arch Ophthalmol. 2004;122(3):369-73.

3. Ramos-Remus C, Suarez-Almazor M, Russell AS. Low tear production in patients with diabetes mellitus is not due to Sjögren's syndrome. Clin Exp Rheumatol. 1994;12(4):375-80.

4. Goebbels M. Tear secretion and tear film function in insulin dependent diabetics. Br J Ophthalmol. 2000;84(1):19-21.

5. Dogru M, Katakami C, Inoue M. Tear function and ocular surface changes in noninsulin-dependent diabetes mellitus. Ophthalmology. 2001;108(3):586-92.

6. Kaiserman I, Kaiserman N, Nakar S, Vinker S. Dry eye in diabetic patients. Am J Ophthalmol. 2005;139(3):498-503.

7. Zimmet P, Alberti KG, Shaw J. Global and societal implications of the diabetes epidemic. Nature. 2001;414(6865):782-7.

8. King H, Aubert RE, Herman WH. Global burden of diabetes, 1995-2025: prevalence, numerical estimates, and projections. Diabetes Care. 1998;21(9):1414-31.

9. Saad MJ. Molecular mechanisms of insulin resistance. Braz J Med Biol Res. 1994;27(4):941-57.

10. Kahn BB. Type 2 diabetes: when insulin secretion fails to compensate for insulin resistance. Cell. 1998;92(5):593-6.

11. Kahn CR, Vicent D, Doria A. Genetics of non-insulin-dependent (type-II) diabetes mellitus. Annu Rev Med. 1996;47:509-31.

12. Brownlee M. Biochemistry and molecular cell biology of diabetic complications. Nature. 2001;414(6865):813-20.

13. The effect of intensive treatment of diabetes on the development and progression of long-term complications in insulin-dependent diabetes mellitus. The Diabetes Control and Complications Trial Research Group. N Engl J Med. 1993;329(14):977-86.

14. Intensive blood-glucose control with sulphonylureas or insulin compared with conventional treatment and risk of complications in patients with type 2 diabetes (UKPDS 33). UK Prospective Diabetes Study (UKPDS) Group. Lancet. 1998;352(9131):837-53.

15. Ebara T, Conde K, Kako Y, Liu Y, Xu Y, Ramakrishnan R, et al. Delayed catabolism of apoB-48 lipoproteins due to decreased heparan sulfate proteoglycan production in diabetic mice. J Clin Invest. 2000;105(12):1807-18.

16. Ginsberg HN. Insulin resistance and cardiovascular disease. J Clin Invest. 2000;106(4):453-8.

17. Wei M, Gaskill SP, Haffner SM, Stern MP. Effects of diabetes and level of glycemia on all-cause and cardiovascular mortality. The San Antonio Heart Study. Diabetes Care. 1998;21(7):1167-72.

18. Ishida N, Rao GN, del Cerro M, Aquavella JV. Corneal nerve alterations in diabetes mellitus. Arch Ophthalmol. 1984;102(9):1380-4.

19. Azar DT, Spurr-Michaud SJ, Tisdale AS, Gipson IK. Altered epithelialbasement membrane interactions in diabetic corneas. Arch Ophthalmol. 1992; 110(4):537-40.

20. Hsueh WA, Law RE. Cardiovascular risk continuum: implications of insulin resistance and diabetes. Am J Med. 1998;105(1A):4S-14S.

21. Jiang ZY, Lin YW, Clemont A, Feener EP, Hein KD, Igarashi M, et al. 
Characterization of selective resistance to insulin signaling in the vasculature of obese Zucker (fa/fa) rats. J Clin Invest. 1999;104(4):447-57.

22. Zecchin HG, Bezerra RM, Carvalheira JB, Carvalho-Filho MA, Metze K, Franchini $\mathrm{KG}$, et al. Insulin signalling pathways in aorta and muscle from two animal models of insulin resistance-the obese middle-aged and the spontaneously hypertensive rats. Diabetologia. 2003;46(4):479-91.

23. Zecchin HG, Priviero FB, Souza CT, Zecchin KG, Prada PO, Carvalheira JB, et al. Defective insulin and acetylcholine induction of endothelial cell-nitric oxide synthase through insulin receptor substrate/Akt signaling pathway in aorta of obese rats. Diabetes. 2007;56(4):1014-24.

24. Du XL, Edelstein D, Rossetti L, Fantus IG, Goldberg H, Ziyadeh F, et al. Hyperglycemia-induced mitochondrial superoxide overproduction activates the hexosamine pathway and induces plasminogen activator inhibitor- 1 expression by increasing Sp1 glycosylation. Proc Natl Acad Sci U S A. 2000;97(22):12222-6.

25. Yagyu H, Kitamine T, Osuga J, Tozawa R, Chen Z, Kaji Y. et al. Absence of ACAT-1 attenuates atherosclerosis but causes dry eye and cutaneous xanthomatosis in mice with congenital hyperlipidemia. J Biol Chem. 2000;275(28): 21324-30.

26. Temelkova-Kurktschiev TS, Koehler C, Henkel E, Leonhardt W, Fuecker K, Hanefeld M. Postchallenge plasma glucose and glycemic spikes are more strongly associated with atherosclerosis than fasting glucose or $\mathrm{HbAlc}$ level. Diabetes Care. 2000;23(12):1830-4.

27. Vlassara H, Bucala R, Striker L. Pathogenic effects of advanced glycosylation: biochemical, biologic, and clinical implications for diabetes and aging. Lab Invest. 1994;70(2):138-51.

28. Alves M, Calegari VC, Cunha DA, Saad MJ, Velloso LA, Rocha EM. Increased expression of advanced glycation end-products and their receptor, and activation of nuclear factor kappa-B in lacrimal glands of diabetic rats. Diabetologia. 2005;48(12):2675-81.

29. Bierhaus A, Schiekofer S, Schwaninger M, Andrassy M, Humpert PM, Chen $\mathrm{J}$, et al. Diabetes-associated sustained activation of the transcription factor nuclear factor-kappaB. Diabetes. 2001;50(12):2792-808.

30. Evans JL, Goldfine ID, Maddux BA, Grodsky GM. Oxidative stress and stress-activated signaling pathways: a unifying hypothesis of type 2 diabetes. Endocr Rev. 2002;23(5):599-622.

31. Stitt AW. Advanced glycation: an important pathological event in diabetic and age related ocular disease. Br J Ophthalmol. 2001;85(6):746-53.

32. Leslie RD. United Kingdom prospective diabetes study (UKPDS): what now or so what? Diabetes Metab Res Rev. 1999;15(1):65-71.

33. Chung H, Tolentino FI, Cajita VN, Acosta J, Refojo MF. Reevaluation of corneal complications after closed vitrectomy. Arch Ophthalmol. 1988;106(7): 916-9.

34. Taylor HR, Kimsey RA. Corneal epithelial basement membrane changes in diabetes. Invest Ophthalmol Vis Sci. 1981;20(4):548-53.

35. Kaji Y. Prevention of diabetic keratopathy. Br J Ophthalmol. 2005;89(3):254-5.

36. Foulks GN, Thoft RA, Perry HD, Tolentino FI. Factors related to corneal epithelial complications after closed vitrectomy in diabetics. Arch Ophthalmol. 1979;97(6):1076-8

37. Hyndiuk RA, Kazarian EL, Schultz RO, Seideman S. Neurotrophic corneal ulcers in diabetes mellitus. Arch Ophthalmol. 1977;95(12):2193-6.

38. Kenyon KR, Stark WJ, Stone DL. Corneal endothelial degeneration and fibrous proliferation after plana vitrectomy. Am J Ophthalmol. 1976;81(4): 486-90.

39. Friend J, Thoft RA. The diabetic cornea. Int Ophthalmol Clin. 1984;24(4): $111-23$.

40. Cousen P, Cackett P, Bennett H, Swa K, Dhillon B. Tear production and corneal sensitivity in diabetes. J Diabetes Complications. 2007;21(6):371-3.

41. Lockwood A, Hope-Ross M, Chell P. Neurotrophic keratopathy and diabetes mellitus. Eye. 2006;20(7):837-9.

42. Seifart U, Strempel I. The dry eye and diabetes mellitus. Ophthalmologe. 1994; 91(2):235-9.

43. Rieger G. The importance of the precorneal tear film for the quality of optical imaging. Br J Ophthalmol. 1992;76(3):157-8.

44. Inoue K, Kato S, Ohara C, Numaga J, Amano S, Oshika T. Ocular and systemic factors relevant to diabetic keratoepitheliopathy. Cornea. 2001;20(8):798-801.

45. Nepp J, Abela C, Polzer I, Derbolav A, Wedrich A. Is there a correlation between the severity of diabetic retinopathy and keratoconjunctivitis sicca? Cornea. 2000;19(4):487-91.

46. Henricsson M, Nilsson A, Janzon L, Groop L. The effect of glycaemic control and the introduction of insulin therapy on retinopathy in non-insulin-dependent diabetes mellitus. Diabet Med. 1997;14(2):123-31.

47. Rakieten N, Rakieten ML, Nadkarni MV. Studies on the diabetogenic action of streptozotocin (NSC-37917). Cancer Chemother Rep. 1963;29:91-8.
48. Junod A, Lambert AE, Orci L, Pictet R, Gonet AE, Renold AE. Studies of the diabetogenic action of streptozotocin. Proc Soc Exp Biol Med. 1967;126(1): 201-5.

49. Reed MJ, Meszaros K, Entes LJ, Claypool MD, Pinkett JG, Gadbois TM, et al. A new rat model of type 2 diabetes: the fat-fed, streptozotocin-treated rat. Metabolism. 2000;49(11):1390-4

50. Kuriyama H, Sasaki K, Fukuda M. Studies on diabetic cataract in rats induced by streptozotocin. II. Biochemical examinations of rat lenses in relation to cataract stages. Ophthalmic Res. 1983;15(4):191-7.

51. Stitt AW, Anderson HR, Gardiner TA, McIntyre I, Archer DB. The combined effects of diabetes and ionising radiation on the rat retina: an ultrastructural study. Curr Eye Res. 1994;13(1):79-86.

52. Cutler LS, Pinney HE, Christian C, Russotto SB. Ultrastructural studies of the rat submandibular gland in streptozotocin induced diabetes mellitus. Virchows Arch A Pathol Anat Histol. 1979;382(3):301-11.

53. Zagon IS, Sassani JW, McLaughlin PJ. Insulin treatment ameliorates impaired corneal reepithelialization in diabetic rats. Diabetes. 2006;55(4):1141-7.

54. Cunha DA, de Alves MC, Stoppiglia LF, Jorge AG, Modulo CM, Carneiro EM, et al. Extra-pancreatic insulin production in RAt lachrymal gland after streptozotocin-induced islet beta-cells destruction. Biochim Biophys Acta. 2007; 1770(8):1128-35.

55. Toda I, Sullivan BD, Rocha EM, da Silveira LA, Wickham LA, Sullivan DA. Impact of gender on exocrine gland inflammation in mouse models of Sjogren's syndrome. Exp Eye Res. 1999;69(4):355-66.

56. Barabino S Dana MR. Animal models of dry eye: a critical assessment of opportunities and limitations. Invest Ophthalmol Vis Sci. 2004;45(6):1641-6.

57. Wakuta M, Morishige N, Chikama T, Seki K, Nagano T, Nishida T. Delayed wound closure and phenotypic changes in corneal epithelium of the spontaneously diabetic Goto-Kakizaki rat. Invest Ophthalmol Vis Sci. 2007;48(2):590-6.

58. Rocha EM, de MLMH, Carvalho CR, Saad MJ, Velloso LA. Characterization of the insulin-signaling pathway in lacrimal and salivary glands of rats. Curr Eye Res. 2000;21(5):833-42.

59. Hann LE, Kelleher RS, Sullivan DA. Influence of culture conditions on the androgen control of secretory component production by acinar cells from the rat lacrimal gland. Invest Ophthalmol Vis Sci. 1991;32(9):2610-21.

60. Adeghate E, Hameed RS. Immunohistochemical localization of orexin-B, orexin-1 receptor, ghrelin, GHS-R in the lacrimal gland of normal and diabetic rats. Peptides. 2005;26(12):2585-9.

61. Mahay S, Adeghate E, Lindley MZ, Rolph CE, Singh J. Streptozotocininduced type 1 diabetes mellitus alters the morphology, secretory function and acyl lipid contents in the isolated rat parotid salivary gland. Mol Cell Biochem. 2004;261(1-2):175-81

62. Nogueira FN, Carvalho AM, Yamaguti PM, Nicolau J. Antioxidant parameters and lipid peroxidation in salivary glands of streptozotocin-induced diabetic rats. Clin Chim Acta. 2005;353(1-2):133-9.

63. Nishida T, Nakagawa S, Manabe R. Superoxide dismutase activity in diabetic rat retina. Jpn J Ophthalmol. 1984;28(4):377-82

64. Zoukhri D, Hodges RR, Byon D, Kublin CL. Role of proinflammatory cytokines in the impaired lacrimation associated with autoimmune xerophthalmia. Invest Ophthalmol Vis Sci. 2002;43(5):1429-36.

65. Rocha EM, Wickham LA, Huang Z, Toda I, Gao J, da Silveira LA, et al. Presence and testosterone influence on the levels of anti- and pro-inflammatory cytokines in lacrimal tissues of a mouse model of Sjogren's syndrome. Adv Exp Med Biol. 1998;438:485-91.

66. Fukushi S, Merola LO, Tanaka M, Datiles M, Kinoshita JH. Reepithelialization of denuded corneas in diabetic rats. Exp Eye Res. 1980;31(5):611-21.

67. Azar DT, Gipson IK. Repair of the corneal epithelial adhesion structures following keratectomy wounds in diabetic rabbits. Acta Ophthalmol Suppl. 1989;192:72-9.

68. Fowler SA. Wound healing in the corneal epithelium in diabetic and normal rats. Exp Eye Res. 1980;31(2):167-79.

69. Zagon IS, Klocek MS, Sassani JW, McLaughlin PJ. Use of topical insulin to normalize corneal epithelial healing in diabetes mellitus. Arch Ophthalmol. 2007;125(8):1082-8.

70. Gonul B, Koz M, Ersoz G, Kaplan B. Effect of EGF on the corneal wound healing of alloxan diabetic mice. Exp Eye Res. 1992;54(4):519-24.

71. Yamada N, Yanai R, Kawamoto K, Nagano T, Nakamura M, Inui M, et al Promotion of corneal epithelial wound healing by a tetrapeptide (SSSR) derived from IGF-1. Invest Ophthalmol Vis Sci. 2006;47(8):3286-92.

72. Yanai R, Yamada N, Inui M, Nishida T. Correlation of proliferative and antiapoptotic effects of HGF, insulin, IGF-1, IGF-2, and EGF in SV40-transformed human corneal epithelial cells. Exp Eye Res. 2006;83(1):76-83.

73. Cunha DA, Carneiro EM, Alves Mde C, Jorge AG, de Sousa SM, Boschero 
$\mathrm{AC}$, et al. Insulin secretion by rat lacrimal glands: effects of systemic and local variables. Am J Physiol Endocrinol Metab. 2005;289(5):E768-75.

74. Kern TS. Contributions of inflammatory processes to the development of the early stages of diabetic retinopathy. Exp Diabetes Res. 2007;95:103.

75. Tracey KJ. Physiology and immunology of the cholinergic antiinflammatory pathway. J Clin Invest. 2007;117(2):289-96.

76. Nguyen DH, Beuerman RW, Meneray M, Toshida H. Sensory denervation modulates eIF-2 alpha kinase expression in the rabbit lacrimal gland. Curr Eye Res. 2006;31(4):287-95.

77. Carter DA, Wobken JD, Dixit PK, Bauer GE. Immunoreactive insulin in rat salivary glands and its dependence on age and serum insulin levels. Proc Soc Exp Biol Med. 1995;209(3):245-50.

78. Westrom BR, Ekman R, Svendsen L, Svendsen J, Karlsson BW. Levels of immunoreactive insulin, neurotensin, and bombesin in porcine colostrum and milk. J Pediatr Gastroenterol Nutr. 1987;6(3):460-5.

79. Rocha EM, Cunha DA, Carneiro EM, Boschero AC, Saad MJ, Velloso LA. Identification of insulin in the tear film and insulin receptor and IGF-1 receptor on the human ocular surface. Invest Ophthalmol Vis Sci. 2002;43(4):963-7.

80. Habib T, Hejna JA, Moses RE, Decker SJ. Growth factors and insulin stimulate tyrosine phosphorylation of the $51 \mathrm{C} / \mathrm{SHIP} 2$ protein. J Biol Chem. 1998;273(29):18605-9.

81. Degenhardt TP, Alderson NL, Arrington DD, Beattie RJ, Basgen JM, Steffes MW, et al. Pyridoxamine inhibits early renal disease and dyslipidemia in the streptozotocin-diabetic rat. Kidney Int. 2002;61(3):939-50.
82. Peponis V, Bonovas S, Kapranou A, Peponi E, Filioussi K, Magkou C, et al. Conjunctival and tear film changes after vitamin $\mathrm{C}$ and $\mathrm{E}$ administration in noninsulin dependent diabetes mellitus. Med Sci Monit. 2004;10(5):CR213-7.

83. Yin MJ, Yamamoto Y, Gaynor RB. The anti-inflammatory agents aspirin and salicylate inhibit the activity of I(kappa)B kinase-beta. Nature. 1998;396(6706): 77-80.

84. Shoelson SE, Lee J, Yuan M. Inflammation and the IKK beta/I kappa B/NFkappa B axis in obesity- and diet-induced insulin resistance. Int J Obes Relat Metab Disord. 2003;27(Suppl 3):S49-52.

85. Beauregard C, Brandt PC. Peroxisome proliferator-activated receptor agonists inhibit interleukin-1beta-mediated nitric oxide production in cultured lacrimal gland acinar cells. J Ocul Pharmacol Ther. 2003;19(6):579-87.

86. Bonini S, Lambiase A, Rama P, Caprioglio G, Aloe L. Topical treatment with nerve growth factor for neurotrophic keratitis. Ophthalmology. 2000;107(7): 1347-51; discussion 1351-2.

87. Brown SM, Lamberts DW, Reid TW, Nishida T, Murphy CJ. Neurotrophic and anhidrotic keratopathy treated with substance $\mathrm{P}$ and insulinlike growth factor 1. Arch Ophthalmol. 1997;115(7):926-7.

88. Watanabe M, Yamagishi-Wang H, Kawaguchi M. Lowered susceptibility of muscarinic receptor involved in salivary secretion of streptozotocin-induced diabetic rats. Jpn J Pharmacol. 2001;87(2):117-24.

89. Schulze S, Sekundo W, Kroll P. Autologous serum versus hyaluronic acid eye drops for the treatment of corneal erosions after vitrectomy in diabetic patients. A prospective randomized study. Ophthalmologe. 2005;102(9):863-8. 